\title{
Residue of ochratoxin A in chicken tissues-risk assessment
}

\author{
Dragan R. Milićević1, Milijan Jovanović², Vesna F. Matekalo-Sverak', Tatjana Radičević1, Milan M. Petrović3, \\ Dubravka Ž. Vuković ${ }^{4}$
}

\section{SUMMARY}

Background: Toxicological investigations of tissues of normally slaughtered chickens were carried out to provide preliminary evaluation of the incidence of OTA in chicken tissues $(n=90)$. Majority of tissue samples were not found to contain measurable amounts of OTA, while in general, the OTA levels found in the analyzed tissue were low.

Arch Oncol 2011;19(1-2):23-7. UDC: $636.09: 615.9: 576.7: 577.112 .4$ DOl: 10.2298/A001102023M

Methods: The presence of OTA in tissue samples was determined by HPLC-FL after liquid-liquid extraction procedure. Method validation was performed according to the Commission Decision 2002/657/EC.

Results: Of the 90 liver, kidney and gizzard samples originating from chicken farms located in the different agricultural areas of Serbia, OTA was reported in 23 (38.33\%), 17 (28.3\%) and 16 (26.6\%) samples, respectively, with levels ranging from 0.14 to $3.9 \mathrm{ng} / \mathrm{g}$ in liver, 0.1 to $7.02 \mathrm{ng} / \mathrm{g}$ in kidneys and 0.25 to $9.94 \mathrm{ng} / \mathrm{g}$ in gizzard. None of the tissue samples contained more than the maximum level $(10 \mathrm{ng} / \mathrm{g})$ recommended by the European Commission.

Conclusion: Low OTA results also suggested that chicken meat available in the retail market is unlikely to pose an adverse health risk to the consumers in respect to OTA toxicity.

Key words: Ochratoxins; Chickens; Risk Assessment; Food Analysis

\section{INTRODUCTION}

Modern industrial poultry production is the fastest and the most efficient way of obtaining high quality products for human consumption of all categories, such as poultry meat and eggs (1). Poultry meat is known as a highly valued food due to its biological and nutritional value primarily for the high protein content with a satisfactory amino acid composition and low energy value. Modern consumers of food require much more than just good taste (2). The most important values have become: quality, health and safety - because it does matter what we put on our plate (3). A healthy diet is safe, nutritious, energy-balanced and gastronomically acceptable and in accordance with age, gender and health status (4).

Toxic substances such as mycotoxins are almost ubiquitous in the environment. Their common occurrence in food and feed poses a threat to health of humans and animals. Ochratoxin A (OTA) is a wide spread mycotoxin produced by several species of the Aspergillus and Penicillium genera and is classified as a possible human carcinogen (group 2B) by the International Agency for Research on Cancer (IARC) (5). Long-term exposure to OTA has been implicated in Balkan Endemic Nephropathy (BEN) and associated with urinary tract tumors because of rather high OTA levels detected in food samples and in blood or urine from affected persons $(5,6)$. OTA enters the food chain either through cereals, oilseeds, fruit (7) and their derived products or through products of animal origin when animals such as swine and poultry are fed OTA contaminated diets (8). OTA has been detected in pigs with a tissue distribution that follows the pattern blood $>$ kidney $>$ liver $>$ muscle $>$ adipose tissue (9-11). Studies have shown that pork products, especially sausages and products that include blood and kidneys, may contain OTA $(12,13)$ and that production procedures such as seasoning and storage have no effect on the reduction of OTA levels (14). Human intake and absorption of OTA were confirmed through the detection of OTA residues in human blood serum, milk and kidney (15). OTA was last evaluated by the Scientific Committee on Food (SCF) when it concluded that OTA possesses carcinogenic, nephrotoxic, teratogenic, immunotoxic and possibly neurotoxic properties. The SCF estimated that the mean dietary intake ranged from 0.7 to $4.6 \mathrm{ng} / \mathrm{kg} \mathrm{BW}$ per day. By combining the average OTA contamination levels in food which is to be consumed with $95 \%$ of probability, the JECFA estimated a dietary exposure of approximately $90 \mathrm{ng} / \mathrm{kg}$ BW per week corresponding to about $13 \mathrm{ng} / \mathrm{kg}$ BW per day.

Poultry meat comprises a substantial portion of the Serbian diet. In fact, the consumption of poultry has increased steadily and now leads in front of pork (17.4 kg and $16 \mathrm{~kg}$, per capita, respectively).

Therefore, the aim of this paper is to bring up to date the current status of OTA contamination of the chicken meat intended for human consumption. In addition, as reports on OTA presence in chicken meat are limited and based on the analysis of OTA in 90 samples of chicken liver, kidneys and gizzard, the risk for the consumer is also assessed.

\section{MATERIAL AND METHODS}

\section{Samples collection}

In the slaughterhouse which processes approximately 200,000 to 250,000 broilers per week, at the end of the $5^{\text {th }}, 6^{\text {th }}$ or $7^{\text {th }}$ fatting week, by random method ( 5 per farm), chickens for slaughtering were selected. A total of 90 livers, kidneys and gizzards of corresponding animals, were collected. The liver and kidneys were removed and weighed. After cutting pieces of kidney for histological examination, the rest of the sample was homogenized and stored at $-20^{\circ} \mathrm{C}$ before analysis.

\section{Chemicals and reagents}

Ochratoxin A crystalline material was purchased from Sigma (St. Louis, MO, USA). Stock concentrated solution was prepared in toluene-acetic acid (99:1 $\mathrm{v} / \mathrm{v}$ ) at a final concentration of $1 \mathrm{mg} / \mathrm{mL}$ and kept under safe conditions at 
$-20^{\circ} \mathrm{C}$ and wrapped in aluminum foil, because OTA gradually breaks down under ultraviolet (UV) light. The OTA working solution was prepared by diluting the stock solution with toluene-acetic acid $(99: 1 \mathrm{v} / \mathrm{v})$ to $\sim 10 \mathrm{ng} / \mathrm{ml}$. The actual concentration of OTA was calculated using a UV spectrophotometer set at $333 \mathrm{~nm}$ (e 5550). After suitable dilutions in water-methanol-acetic acid (50:49:1 v/v/ v), the working solution was used to prepare the external calibration curve. A working standard OTA for HPLC was prepared daily just before starting the injection of a series of samples. Other reagents were HPLC grade. All other chemicals were reagent grade or chemically pure.

\section{Extraction and cleanup for ochratoxin analyses from the kidney, liver and gizzard}

Kidney, liver and gizzard analyses were performed by the method of Matrella et al., (10), which briefly includes a double extraction with acidic ethyl acetate. The organic phase was removed and extracted with 0.5 $\mathrm{M} \mathrm{NaHCO}_{3}, \mathrm{pH}$ 8.4. The aqueous extract was adjusted to $\mathrm{pH} 2.5$ with 7 $\mathrm{M} \mathrm{H}_{3} \mathrm{PO}_{4}$. OTA was finally back extracted into ethyl acetate $(3 \mathrm{ml})$. The organic phase was evaporated to dryness under $\mathrm{N}_{2}$ steam and reconstituted in 150- $\mu \mathrm{L}$ mobile phases and a $20 \mu \mathrm{L}$ aliquot was injected.

\section{Chromatographic conditions (HPLC)}

An aliquot of $20 \mu \mathrm{L}$ for serum samples and $50 \mu \mathrm{L}$ for kidneys, liver and gizzard samples were injected onto a Waters Symmetry Shield RP (Reversed Phase) 18, high pressure liquid chromatography column (length and inner diameter $150 \times 4.6 \mathrm{~mm}$, particle size $5 \mu \mathrm{m}$ ) on a Waters Alliance $2695 \mathrm{HPLC}$ system. The column was eluted with $4 \%$ acetic acid and acetonitrile (32:68 $\mathrm{v} / \mathrm{v}$ ) at $25^{\circ} \mathrm{C}$ and a flow rate of $1 \mathrm{~mL} / \mathrm{min}$. Measurements were performed by fluorescence detection at wavelengths of $334 \mathrm{~nm}$ (excitation) and $460 \mathrm{~nm}$ (emission) gains 10. A volume of $20 \mu \mathrm{L}$ was injected for the standards and $20 \mu \mathrm{L}$ for the samples. For more accuracy, $40 \mu \mathrm{L}$ was re-injected in the case of the samples with an amount of OTA near the detection limit.

\section{Statistical analysis}

Descriptive statistics of the data set were performed with a standard program and descriptive data were presented as means, standard deviation (SD), and range, for continuous variables. Statistical differences in the mean levels of OTA contamination across the three groups of positive samples were determined by one-way ANOVA $(p<0.05)$. Significance was set at $p<0.05$.

\section{RESULTS}

\section{Sample analysis}

The performances of the employed analytical methods complied with the acceptable range set by the Commission Decision (EC) 2002/657 (16).

A total of 270 tissue samples subjected on the OTA presence were analyzed. The incidence of OTA contamination in liver, kidneys and gizzard is summarized in Tables 1 and 2. None of 90 tissue samples originating from the chicken farms located in the central agricultural area of Serbia, contained OTA. Of the 90 liver, kidneys and gizzard samples originating from the chicken farms located in the northern agricultural area of Serbia, OTA was reported in 23 (38.33\%), 17 (28.3\%) and 16 (26.6\%) samples, respectively. The data in Table 2 show that majority (124) of these samples did not contain ochratoxin $A$ and the rest largely had concentrations close to the detection limit. It should be noted that the samples from both zones were not collected at the same time. OTA levels in liver were slightly higher than those in kidneys and gizzard, but this difference was not statistically significant $(p<0.05)$. The average level of OTA in liver was $0.58 \pm 1.04 \mathrm{ng} / \mathrm{g}$ (range 0.14-3.9 $\mathrm{ng} / \mathrm{g}$ ), whereas OTA average values in kidneys and gizzard were $0.51 \pm 1.38 \mathrm{ng} / \mathrm{g}$ (range 0.1 to $7.02 \mathrm{ng} / \mathrm{g}$ ), and $0.51 \pm 1.75 \mathrm{ng} / \mathrm{g}$ (range $0.25-9.94 \mathrm{ng} / \mathrm{g}$ ) respectively. High values of the standard deviation is due to two samples in kidneys, and one in gizzard that showed a concentration of OTA up to $7.02 \mathrm{ng} / \mathrm{g}$ and $9.5 \mathrm{ng} / \mathrm{g}$, respectively. Although there was obvious difference in the mean value of contamination in samples from different locations, it was not statistically significant. Generally, OTA level in tissues was related to location of the farm.

All the analyzed tissue samples were below the limit established by JECFA (Joint FAO/WHO Expert Committee on Food Additives) (10 ng/g) (17). Only one sample of gizzard contained OTA $(9.94 \mathrm{ng} / \mathrm{g})$, which is close to the maximum permissible toxin level defined in Serbia, including those proposed by the JECFA.

Table 1. Incidence of OTA in tissue of slaughtered chicken from the central region

\begin{tabular}{|c|c|c|c|c|c|c|}
\hline \multirow{2}{*}{$\begin{array}{l}\text { Locations of farms and } \\
\text { period of sampling }\end{array}$} & \multicolumn{2}{|c|}{ Liver $(\mathrm{N}=30)$} & $\begin{array}{l}\text { Incidenc } \\
\text { Kidneys }\end{array}$ & & \multicolumn{2}{|c|}{ Gizzard $(N=30)$} \\
\hline & positive samples (\%) & $\underset{\text { (min-max) }}{\bar{X} \pm S D}$ & positive samples (\%) & $\underset{\text { (min-max) }}{\bar{X} \pm S D}$ & positive samples (\%) & $\underset{\text { (min-max) }}{\bar{X}_{ \pm S D}}$ \\
\hline $\begin{array}{c}\text { A } \\
\text { January }\end{array}$ & nd & nd & nd & nd & nd & nd \\
\hline $\begin{array}{c}\text { B } \\
\text { January }\end{array}$ & nd & nd & nd & nd & nd & nd \\
\hline $\begin{array}{c}\text { C } \\
\text { January }\end{array}$ & nd & nd & nd & nd & nd & nd \\
\hline$\stackrel{D}{\text { February }}$ & nd & nd & nd & nd & nd & nd \\
\hline $\begin{array}{c}\text { E } \\
\text { February }\end{array}$ & nd & nd & nd & nd & nd & nd \\
\hline $\begin{array}{c}\mathrm{F} \\
\text { February }\end{array}$ & nd & nd & nd & nd & nd & nd \\
\hline TOTAL & nd & nd & nd & nd & nd & nd \\
\hline
\end{tabular}


Table 2. Incidence of OTA in tissue of slaughtered chicken from the northern region

\begin{tabular}{|c|c|c|c|c|c|c|}
\hline \multirow{3}{*}{$\begin{array}{l}\text { Locations of farms and } \\
\text { period of sampling }\end{array}$} & \multicolumn{6}{|c|}{ Incidence of OTA } \\
\hline & \multicolumn{2}{|c|}{ Liver $(\mathrm{N}=60)$} & \multicolumn{2}{|c|}{ Kidneys $(\mathrm{N}=60)$} & \multicolumn{2}{|c|}{ Gizzard $(N=60)$} \\
\hline & positive samples (\%) & $\begin{array}{c}\bar{X} \pm S D \\
(\min -\max )\end{array}$ & positive samples (\%) & $\begin{array}{c}\bar{X} \pm S D \\
\text { (min-max) }\end{array}$ & $\begin{array}{c}\text { positive samples } \\
(\%)\end{array}$ & $\begin{array}{c}\bar{X} \pm S D \\
\text { (min-max) }\end{array}$ \\
\hline $\begin{array}{c}\text { A } \\
\text { March }\end{array}$ & $4(80)$ & $\begin{array}{c}2.19 \pm 1.69 \\
(1.3-3.9)\end{array}$ & $3(60)$ & $\begin{array}{c}0.23 \pm 0.21 \\
(0.35-0.4)\end{array}$ & $1(20)$ & $\begin{array}{c}0.37 \pm 0.83 \\
(1.85)\end{array}$ \\
\hline $\begin{array}{c}\text { B } \\
\text { April }\end{array}$ & $5(100)$ & $\begin{array}{l}0.26 \pm 0.09 \\
(0.14-0.38)\end{array}$ & $5(100)$ & $\begin{array}{l}3.36 \pm 3.04 \\
(0.71-7.02)\end{array}$ & $5(100)$ & $\begin{array}{c}0.84 \pm 0.53 \\
(0.25-1.4)\end{array}$ \\
\hline $\begin{array}{c}\text { C } \\
\text { April }\end{array}$ & $3(60)$ & $\begin{array}{l}1.2 \pm 1.42 \\
(0.53-2.76)\end{array}$ & $3(60)$ & $\begin{array}{c}1.09 \pm 4.45 \\
(0.1-4.74)\end{array}$ & $1(20)$ & $\begin{array}{c}1.99 \pm 4.45 \\
(9.94)\end{array}$ \\
\hline $\begin{array}{l}\text { D } \\
\text { May }\end{array}$ & nd & nd & nd & nd & $3(60)$ & $\begin{array}{c}2.23 \pm 4.09 \\
(0.78-9.5)\end{array}$ \\
\hline $\begin{array}{c}\text { A } \\
\text { June }\end{array}$ & $2(40)$ & $\begin{array}{c}0.89 \pm 1.34 \\
(1.45-3.0)\end{array}$ & $3(60)$ & $\begin{array}{c}0.45 \pm 0.5 \\
(0.4-1.2)\end{array}$ & $1(20)$ & $\begin{array}{c}1.07 \pm 2.39 \\
(5.34)\end{array}$ \\
\hline $\begin{array}{c}E \\
\text { June }\end{array}$ & $4(80)$ & $\begin{array}{c}1.29 \pm 1.17 \\
(0.45-2.9)\end{array}$ & $3(60)$ & $\begin{array}{c}1.34 \pm 1.45 \\
(1.0-3.1)\end{array}$ & $4(80)$ & $\begin{array}{c}1.05 \pm 1.12 \\
(0.35-2.9)\end{array}$ \\
\hline $\begin{array}{c}F \\
\text { June }\end{array}$ & nd & nd & nd & nd & nd & nd \\
\hline $\begin{array}{l}\text { G } \\
\text { July }\end{array}$ & nd & nd & nd & nd & nd & nd \\
\hline $\begin{array}{c}\mathrm{H} \\
\text { July }\end{array}$ & nd & nd & nd & nd & nd & nd \\
\hline $\begin{array}{c}\text { I } \\
\text { September }\end{array}$ & $3(60)$ & $\begin{array}{l}1.16 \pm 1.08 \\
(1.67-2.25)\end{array}$ & nd & nd & $1(20)$ & $\begin{array}{c}0.08 \pm 0.18 \\
(0.4)\end{array}$ \\
\hline $\begin{array}{c}\text { A } \\
\text { September }\end{array}$ & $2(40)$ & $\begin{array}{c}0.46 \pm 0.64 \\
(1.1-1.22)\end{array}$ & nd & nd & nd & nd \\
\hline $\begin{array}{c}J \\
\text { October }\end{array}$ & nd & nd & nd & nd & nd & nd \\
\hline TOTAL & $23(38.33)$ & $\begin{array}{l}0.58 \pm 1.04 \\
(0.14-3.9)\end{array}$ & $17(28.33)$ & $\begin{array}{l}0.51 \pm 1.38 \\
(0.1-7.02)\end{array}$ & $16(26.6)$ & $\begin{array}{l}0.51 \pm 1.75 \\
(0.25-9.94)\end{array}$ \\
\hline
\end{tabular}

$\mathrm{N}$ - total number of analyzed samples, nd - non-detectable, $\bar{X}$ - arithmetic mean (conc. below LOD are regarded as zero), SD - standard deviation

\section{DISCUSSION}

Currently, OTA is the most probable mycotoxin involved in the Balkan nephropathy (BEN) endemic and some renal tumours could be involved in the same pathologies in other European countries (6). Potential risks for animal and human health mainly depend on the duration and OTAexposure level. Dietary exposure to OTA varies considerably depending on different factors, among which food-processing systems must be considered. These systems are often traditional and characteristic of the different geographical regions (18). Mycotoxins, in general, are stable compounds, and OTA, in particular, is a moderately heat stable molecule that can survive most food processing operations and, therefore, it appears in final and derived products (19).

The very limited data of spontaneous occurrence of ochratoxicosis in poultry in Serbia are available. Therefore, it was very difficult to compare our results with ones obtained with different analytical methodology. The results from ochratoxin $A$ analysis of chicken tissues in this investigation are similar to the results from previous findings about natural occurrences of ochratoxicosis in poultry and those reported in the EFSA and the SCOOP reports.

The data confirm those of the previous studies that some inhabitants have moderate to very high exposure to OTA that is, in part, reflected by high levels in blood and urine. However, there is no direct correlation between
OTA in the blood or urine and OTA consumed, thus OTA in the blood or urine cannot be recommended as a biomarker of OTA exposure.

Convincing evidences indicate that exposure to OTA, results in DNA damage in the kidney, liver and testicles. OTA produces an inhibition of protein synthesis and lipid peroxidation by oxidative processes (20). These mechanisms may generate nephrotoxic, neurotoxic and immunotoxic effects (21-23). The mechanisms by which OTA is carcinogenic are not entirely elucidated and two hypotheses are still under discussion: (i) an indirect mechanism which would result in a classification as an epigenetic carcinogen $(24,25)$ or (ii) due to direct covalent binding of OTA on DNA, suggesting genotoxic mechanisms being involved in the carcinogenicity $(26,27)$. Although there is evidence for a time- and dose-dependent induction of DNA lesions in vivo when applying the 32P-postlabeling technique, the chemical identities of adducts and metabolites implicated, need to be elucidated (28).

Toxicokinetics are an important determinant in the toxicity of OTA (29). The toxic-kinetic parameters of OTA have not been well determined in humans, but in some animal studies OTA showed high avaliability after oral administration (30). OTA binds rapidly and with high affinity to plasma proteins with increased T1/2 values (31). The metabolism in humans is basically produced through cytochrome P-450 (32) generating less toxic metabolites (33) which are eliminated in urine and feces (34). Also, reabsorption of OTA from the intestine, enterohepatic recirculation, and 
reabsorption in the kidney proximal and distal tubules favor its accumulation in the organism (30). In humans, OTA is rather persistent, with a serum half-life of about 35 days, due to unfavorable elimination kinetics (35). OTA can cross the placenta and is excreted in animal milk (36).

\section{Risk assessment}

The most recent international exposure assessments were performed respectively by the Scientific Committee on Food (SCF) and the JECFA (37). The SCF estimated that the mean dietary intake ranged from 0.7 to $4.6 \mathrm{ng}$ OTA/kg BW per day. By combining the average contamination levels with the $95^{\text {th }}$ percentile of food consumption the JECFA estimated a dietary exposure of approximately $90 \mathrm{ng} / \mathrm{kg}$ BW per week corresponding to about $13 \mathrm{ng} / \mathrm{kg}$ BW per day. Exposure seems to be associated predominantly with the consumption of contaminated plant-derived products, and only to a minor extent to foods of animal origin (37).

It has been shown that chicken meat and meat products are the minor contributors to OTA intake. Data on the exposure assessment of Serbian population to OTA from the consumption of chicken meat are estimated for the first time in this investigation. OTA daily intake estimated in this study is only for orientation purposes and the values obtained need to be checked in the future since number of samples investigated is limited. In Serbia, since the chicken meat consumption is $17.5 \mathrm{~kg}$ per year (i.e. $47.94 \mathrm{~g}$, per day), and the average OTA levels in the liver, kidneys and gizzard are $0.58 \mathrm{ng} / \mathrm{g}$ and $0.51 \mathrm{ng} / \mathrm{g}$, respectively, the estimated daily intake of OTA through chicken meat by a $60 \mathrm{~kg}$ adult is $0.46 \mathrm{ng} \mathrm{kg-1} \mathrm{b.W.}$ and $0.40 \mathrm{ng} \mathrm{kg}-1 \mathrm{BW}$, respectively. This value is below the OTA Tolerable Daily Intake (TDI) estimated by JECFA and EFSA and it can be concluded that there is no significant toxicological risk for Serbian consumers. Additionally, it should be mentioned that the studies were carried out in a region with a long tradition of excellent agriculture and that tissue samples represent a random population of chicken, that were believed to have been exposed to low doses of ochratoxin $A$.

\section{CONCLUSION}

The results found in this study suggest that, in general, OTA contamination in chicken meat originating from different parts of Serbia is low. Of 270 tissue samples tested, measurable amounts of OTA were found in 56 tissue samples, which accounts for $20.7 \%$ of all samples.

The actual concentration in chicken tissues is generally very low, and hence, for the consumer the contribution to the total intake of ochratoxin A from chicken products is very small compared with other sources. However, the daily intake of OTA through chicken meat depends on (1) the concentration in the food, (2) the amount consumed, (3) the frequency of consumption and (4) the consumers' preferences. To protect consumer health and to reduce economic losses, surveillance and control of mycotoxins in food and feed has become a major objective for producers, regulatory authorities and researchers worldwide.

\section{Acknowledgements}

This study was funded by the Ministry of Science and Technological Development, Belgrade, Serbia (project code TP-20207A). We are grateful to the Ministry for their understanding and support to veterinary development.

\section{Conflict of interest}

We declare no conflict of interest.

\section{REFERENCES}

1 Resurrección AVA. Sensory aspects of consumer choices for meat and meat products. Meat Sci. 2004;66(1):11-20.

2 Hernández JM. Sensory perception of quality of products across Europe: A case study on poultry quality. In Sensory evaluation - more than just food, ESN Conference, AINIA, Madrid; 2005.

3 Trienekens J, Zuurbier P. Quality and safety standards in the food industry. International J Prod Econom. 2008;113:107-22.

4 Biesalski HK. Meat as a component of a healthy diet - Are there any risks or benefits if meat is avoided in the diet? Meat Sci. 2005;70:509-24.

5 IARC (International Agency for Research on Cancer), Monograph on the Evaluation of Carcinogenic Risk to Humans. Some Naturally Occurring Substances: Food Items and Constituents, Heterocyclic Aromatic Amines and Mycotoxins. IARC Lyon; 1993. p. 489.

6 Castegnaro M, Canadas D, Vrabcheva T, Petkova-Bocharova T, Chernozemsky IN, Pfohl-Leszkowicz A. Balkan endemic nephropathy: role of ochratoxins A through biomarkers. Mol Nutr Food Res. 2006;50:519-29.

7 Duarte SC, Pena A, Lino CM. A review on ochratoxin A occurrence and effects of processing of cereal and cereal derived food products. Food Microb. 2010;27:187-98.

8 EFSA, Opinion of the Scientific Panel on Contaminants in the Food Chain on a request from the Commission related to ochratoxin $A$ (OTA) as undesirable substance in animal feed. Adopted on 22 September 2004. EFSA J. 2004;101:1-36.

9 Curtui VG, Gareis M, Usleber E, Märttbauer E, Survey of Romanian slaughtered pigs for the occurrence of mycotoxins ochratoxins $A$ and $B$, and zearalenone. Food Addit Contam. 2001;18:730-8.

10 Martella R, Monaci L, Milillo MA, Palmisano F, Tantillo MG. Ochratoxin A determination in paired kidneys and muscle samples from swine slaughtered in southern Italy. Food Control. 2006;17:114-7.

11 Milićević, D, Juric V, Stefanovic S, Jovanovic M, Jankovic S. Survey of slaughtered pigs for occurrence of ochratoxin A and porcine nephropathy in Serbia. Int $J$ Mol Sci. 2008;9:2169-83.

12 Chiavaro E, Lepiani A, Colla F, Bettoni P, Pari E, Spotti E. Ochratoxin A determination in ham by immunoaffinity clean-up and a quick fluorometric method. Food Addit Contam. 2002;19:575-81.

13 Monaci L, Palmisano F, Matrella R, Tantillo G. Determination of ochratoxin A at part-per-trillion level in Italian salami by immunoaffinity clean-up and highperformance liquid chromatography with fluorescence detection. J Chromatogr A. 2005;1090:184-7.

14 Malagutti L, Zanotti M, Scampini A, Sciaraffia F. Effects of ochratoxin A on heavy pig production. Anim Res. 2005;54:179-84.

15 Assaf H, Betbeder AM, Creppy EE, Pallardy M, Azouri H. Ochratoxin A levels in human plasma and foods in Lebanon. Hum Exp Toxicol .2004;23: 495-501.

16 EC, Commission Decision (2002/657/EC) of 12 August 2002 implementing Council Directive 96/23/EC concerning the performance of analytical methods and the interpretation of results (Text with EEA relevance) (notified under document number C(2002) 3044). 0J. EU. 2002:L 221/8-36. 
17 JEFCA (Joint FAO/WHO Expert Committee on Food Additives). Ochratoxin A, Safety Evaluation of Certain Mycotoxins in Food; WHO Food Additives Series 47; FAO Food and Nutrition Paper 74. Geneva, Switzerland: WHO; 2001. p. 281.

18 Valle-Algarra, FM, Mateo EM, Medina Á, Mateo F, Gimeno-Adelantado JV, Jiménez M. Changes in ochratoxin $A$ and type $B$ trichothecenes contained in wheat flour during dough fermentation and bread baking. Food Addit. Contam. - Part A 2009:26:896-906.

19 Bullerman LB, Bianchini A. Stability of mycotoxins during food processing. Int. J. Food Microbiol. 2007;119:140-6.

20 Kamp HG, Eisenbrand G, Schlatter J, Würth K Janzowski C. Ochratoxin A: induction of oxidative DNA damage, cytotoxicity and apoptosis in mammalian cell lines and primary cells. Toxicology. 2005;206:413-25.

21 Luhe A, Hildebrand H, Bach U. A new approach to studying ochratoxin A (OTA)induced nephrotoxicity: expression profiling in vivo and in vitro employing CDNA microarrays. Toxicol. Sci. 2003;73(2):315-28.

22 Šegović Klarić M, Rumora L, Ljubanović D, Pepeljnjak S. Cytotoxicity and apoptosis induced by fumonisin $B 1$, beauvericin and ochratoxin $A$ in porcine kidney PK15 cells: effects of individual and combined treatment. Arch Toxicol. 2008;82:247-55.

23 Álvarez L, Gil AG, Ezpeleta 0, Garciá Jalon JA, López de Cerain A. Immunotoxic effects of Ochratoxin A in wistar rats after oral administration. Food Chem Toxicol. 2004:42:825-34.

24 O'Brien E, Dietrich DR. Ochratoxin A: the continuing enigma. Crit Rev Toxicol. 2005;35:33-60.

25 Turesky RJ. Perspective: Ochratoxin A is not a genotoxic carcinogen. Chem Res Toxicol. 2005;18:1082-90.

26 Pfohl-Leszkowicz A, Manderville RA. Ochratoxin A: an overview on toxicity and carcinogenicity in animals and humans. Mol Nutr Food Res. 2007;51:61-99.

27 Manderville RA, Pfohl-Leszkowicz A. Genotoxicity of Chlorophenols and Ochratoxin A. Adv Mol Toxicol. 2006;1:73-118.

28 Pfohl-Leszkowicz A, Castegnaro M. Further arguments in favor of direct covalent binding of Ochratoxin A (OTA) after metabolic biotransformation. Food Addit Contam. 2005;22 Suppl 1:75-87.

29 Hoffmann D, Adler M, Vaidya V, Rached E, Mulrane L, Gallagher WM, et al. Performance of novel kidney biomarkers in preclinical toxicity studies. Toxicol Sci. 2010;116:8-22.

30 Muñoz K, Blaszkewicz M, Degen GH. Degen. Simultaneous analysis of ochratoxin $A$ and its major metabolite ochratoxin alpha in plasma and urine for an advanced biomonitoring of the mycotoxin. Journal of Chromatography B. 2010;878:2623-9.

31 Mally A, Keim-Heusler $H$, Amberg A, Kurz M, Zepnik $H$, Mantle $P$, et al. Biotransformation and nephrotoxicity of ochratoxin $B$ in rats. Toxicol Appl Pharmacol. 2005;206:43-53.

32 Šegović Klarić M, Daraboš D, Rozgaj R, Kašuba V, Pepeljnjak S. Beauvericin and ochratoxin A genotoxicity evaluated using the alkaline comet assay: single and combined genotoxic action. Arch Toxicol. 2010;84:641-50.

33 Fazecas B, Tar A, Kovacs M. Ochratoxin a content of urine samples of healthy humans in Hungary. Acta Vet Hung. 2005;53:35-44.

34 Hoffmann D, Fuchs TC, Henzler T, Matheis KA, Herget T, Dekant W, et al. Evaluation of a urinary kidney biomarker panel in rat models of acute and subchronic nephrotoxicity. Toxicology. 2010;277:49-58.

35 Scott PM. Biomarkers of human exposure to ochratoxin A. Food Addit Contam. 2005;22 Suppl 1:99-107.
36 Valenta H, Goll M. Determination of ochratoxin A in regional samples of cow's milk from Germany. Food Addit Contam. 1996;13:669-76.

37 EFSA. Opinion of the Scientific Panel on Contaminants in the Food Chain on a request from the Commission related to ochratoxin $A(O T A)$ as undesirable substance in animal feed. Adopted on 4 April 2006. The EFSA Journal. 2006;365:1-56. 